
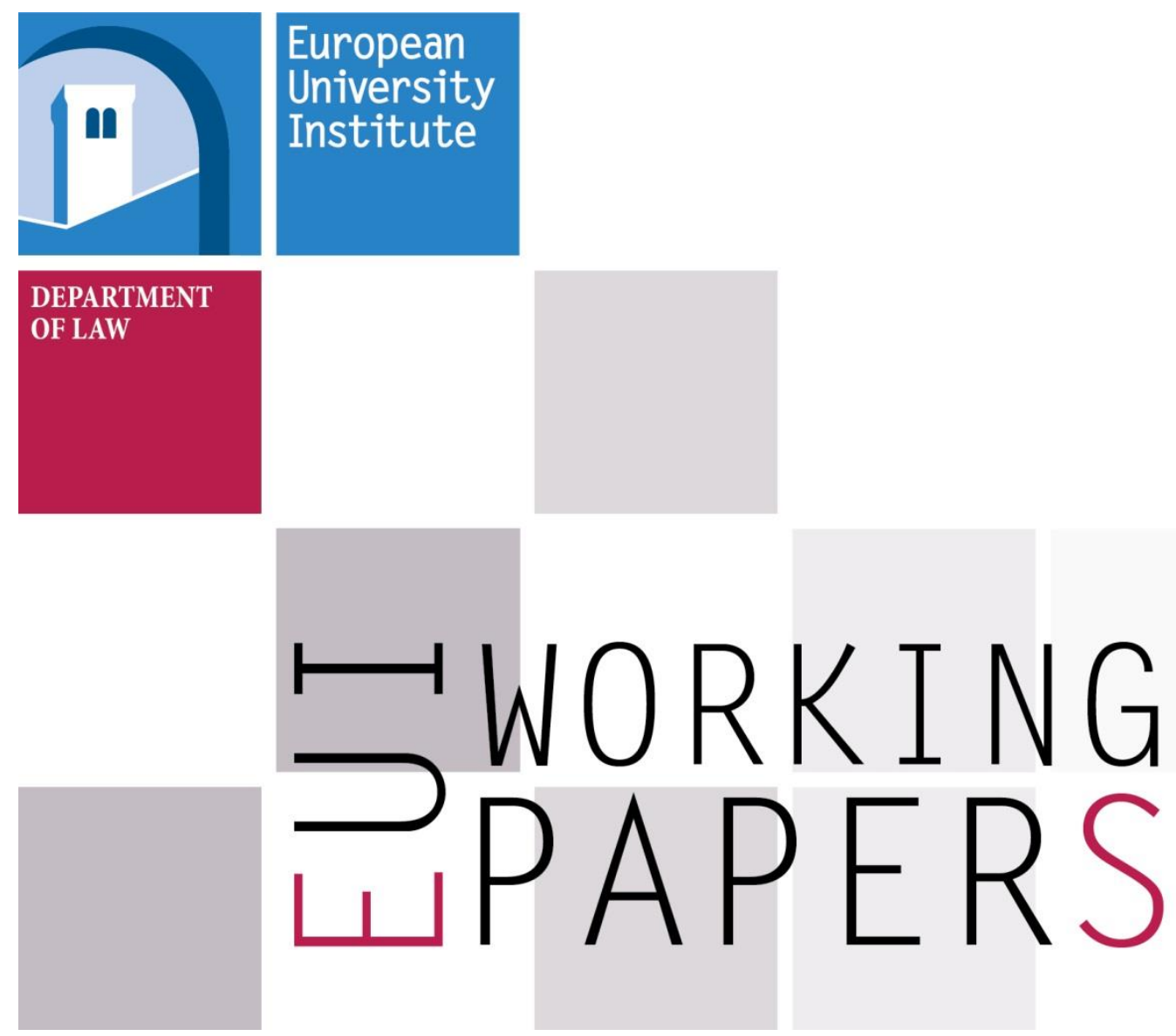

LAW 2015/30

Department of Law

Between symbolism and incrementalism:

Moving forward with the gender equality project in Poland

Anna Śledzińska-Simon and Adam Bodnar 

European University Institute

Department of Law

\section{BETWEEN SYMBOLISM AND INCREMENTALISM:}

Moving ForWARD WiTh THE GENDER EQUALITy PROJECT IN POLAND

Anna Śledzińska-Simon and Adam Bodnar

EUI Working Paper LAW 2015/30 
This text may be downloaded for personal research purposes only. Any additional reproduction for other purposes, whether in hard copy or electronically, requires the consent of the authors. If cited or quoted, reference should be made to the full name of the authors, the title, the working paper or other series, the year, and the publisher.

ISSN 1725-6739

(C) Anna Śledzińska-Simon and Adam Bodnar, 2015

Printed in Italy

European University Institute

Badia Fiesolana

I-50014 San Domenico di Fiesole (FI)

Italy

www.eui.eu

cadmus.eui.eu 


\section{Legal Struggles and Political Mobilization around Gender Quotas}

This paper is part of a case study series stemming from a project, "Gender quotas in Europe: Towards European Parity Citizenship?" funded by the European University Institute Research Council and Jean Monnet Life Long Learning Programme under the scientific coordination of Professors Ruth RubioMarín and Eléonore Lépinard. Gender quotas are part of a global trend to improve women's representation in decision-making bodies. In the past decade they have often been extended in terms of the numbers to be reached ( 40 or 50\% instead of 30\%), and in terms of the social field they should apply to (from politics to the economy to the administration). The aim of the project is to assess and analyze this global trend in the European context, comparing the adoption (or resistance to) gender quotas in 13 European countries in the fields of electoral politics, corporate boards and public bodies.

The case-studies in this series consider the legal struggles and political mobilization around Gender Quotas in Austria, Belgium, Denmark, France, Germany, Italy, Norway, Poland, Portugal, Slovenia, Spain, Sweden, and the U.K. They were presented and discussed in earlier versions at a workshop held in September 2014 at the EUI. Based on the workshop method, all working papers have reflected on similar aspects raised by their country case, concerning: 1) domestic/national preconditions and processes of adoption of gender quotas; 2) transnational factors; 3 ) legal and constitutional challenges raised by gender quotas in both the political and economic spheres; and 4) new frontiers in the field.

The working papers will be also made available on the blog of the workshop, where additional information on the experts and country information sheets can be found, and new developments can be shared: https://blogs.eui.eu/genderquotas. 



\section{Author Contact Details}

\section{Anna Śledzińska-Simon}

Assistant Professor

Chair of Constitutional Law

Department of Law, Administration and Economics

University of Wrocław

A.Simon@prawo.uni.wroc.pl

\section{Adam Bodnar}

Vice-President of the Helsinki Foundation of Human Rights in Warsaw;

Assistant Professor Institute of Human Rights

Warsaw University of Law and Administration

A.Bodnar@hfhr.org.pl 


\begin{abstract}
The purpose of this paper is to examine whether the recently adopted law on gender electoral quotas marks a change in the approach to gender issues and gender equality in Poland. It also aims to describe the trajectory of women's movement in a post-Communist country and to identify causes related to the role of women in the Solidarity movement that resulted in low visibility of women in government and decision-making positions. The paper departs from the assumption that Poland is not moving away from a narrowly conceived equal rights/opportunities model, because such model has not yet been fully implemented. In the context of the present 'war on gender', women's full political, economic, social, and more specifically, private citizenship is a long-term project. As of now, women remain instrumental for achieving political parties' further aims, and any gestures that seem to advance women's position in the public sphere are usually merely symbolic. Yet, the emergence of a strong women's movement helps to frame the public discourse in gendered terms and gradually include its propositions in the mainstream policy.
\end{abstract}

\title{
Keywords
}

Gender equality, political representation, quota, Poland 
Table of contents

SETTLING THE UNSETTLED PROBLEM - WOMEN'S VISIBILITY IN POLITICS ................................ 1

GENDER EQUALITY AND THE PROCESS OF EUROPEANIZATION ............................................... 4

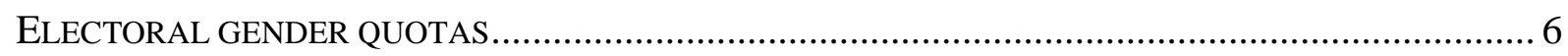

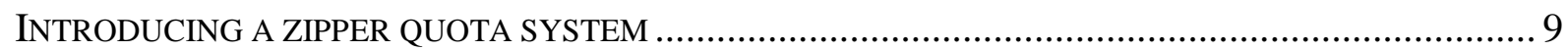

GENDER QUOTAS IN ACADEMIA, JUDICIARY AND CORPORATE BOARDS .................................... 11

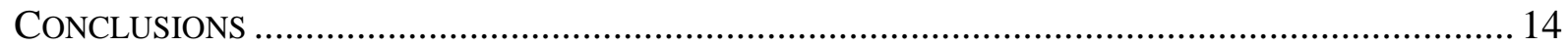

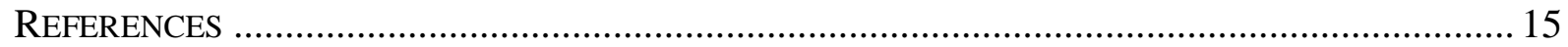





\section{Settling the unsettled problem - women's visibility in politics}

Various stages in the Polish women's struggle for equal status have coincided with important moments in Polish history. Yet, Polish women fighting for national independence did not have an equal share in the victory because they were not rewarded with spoils and privileges of power after the fall and rise of political regimes. Needless to say, their participation in the government after 1918, 1945 and 1989 remained merely symbolic.

Already by the $19^{\text {th }}$ century, the trajectory of the Polish women's movement was different than what was being experienced in the West. Małgorzata Fuszara rightly notices that the lack of national independence prevented women's groups from focusing on women's rights, and they instead relied on tradition. In the reaction to the oppressive reality in Poland, women did not seek emancipation but rather the preservation of national tradition, customs, culture, history and national heritage. As a result, the focus on tradition did not change social relations between men and women but rather strengthened the sexual contract (Fuszara, 2012). Moreover, it is believed that Catholic religion, tradition and family values laid the foundation of national independence because they allowed the Polish nation to thrive notwithstanding wars, partitions and political oppression.

Although Polish women obtained electoral rights in 1919, they have lacked critical mass in Parliament ever since (Fuszara, 2009; 2010). Between 1919 and 1939, only 1.9\% of deputies in the Lower Chamber and 3.8\% of the Upper Chamber were women, whereas between 1945 and 1989 female deputies never had more than $23 \%$ of seats in the unicameral Parliament. Currently, there are $23 \%$ women in the Lower Chamber and 13\% in the Senate. Thus, for a large part of Polish history, not only were Polish women invisible in the political arena, but gender equality and women's rights were also left outside of the political mainstream.

Even in the Communist regime, which is typically associated with gender equality and the image of a female tractor driver as a symbol of women's emancipation, men never entered the private domain. Although the Communist ideology promoted participation of women in certain professions, a patriarchal model of family prevailed in the society and contributed to unequal opportunities and pay for men and women, exclusion of women from managerial posts and their relegation to low-paid sectors and positions, as well as banning women's access to certain traditionally male professions. Most of these culturally-entrenched problems persist today.

Paradoxically, the emergence of the Solidarity movement strengthened patriarchal relations in the society. Anecdotally, during the general workers' strikes in the 1980s, women were requested to stay at home and not to disturb men in their actions. Thus, the Solidarity movement has a male face in national memory, while the role of female oppositionists is frequently forgotten. Also, women were almost completely unrepresented in the 1989 Round Table Talks (Penn, 2005). As a result, after the fall of Communism only male oppositionists occupied the positions of power, and women's issues were exclusively in the agenda of an emerging women's movement (Fuszara, 2006).

In the 1990s new women's organizations aimed to respond to such 'taboo' questions as reproductive rights, sexual education or access to contraceptives. One of the most fiercely debated problems concerned abortion. Yet, women's organizations had little say on the final outcome of this debate as the Catholic Church took advantage of the historical role it played in the 1980s and managed to secure restrictive abortion laws, allowing for termination of pregnancy only in case of rape, genetic disease of the foetus or a threat to woman's health or life. ${ }^{1}$ The so-called 'abortion compromise' made in 1993 between the government and the Catholic Church was never accepted by the feminist organizations,

\footnotetext{
${ }^{1}$ Similarly, there is no progress with regard to regulation of such issues like in-vitro, the status of embryos, or the ratification of the Oviedo Convention for the Protection of Human Rights and Dignity of the Human Being with regard to the Application of Biology and Medicine.
} 
like the Federation for Women and Planned Parenthood (Federacja na Rzecz Kobiet i Planowania Rodziny) that took the lead in the public discourse on women's rights and relevant litigation (Szczuka 2004).

In fact, the early women's movement in post-Communist Poland was quite massive but highly divided between different factions, groups, intellectual leaders, strategies or political agendas (Czerwińska \& Piotrowska, 2004). The feminist movement mobilized around specific women's rights problems such as reproductive rights, violence against women, human trafficking and prostitution - starting with awareness raising campaigns and the establishment of grass-roots organizations (Nowakowska \& Jabłonska, 2000: 147; Durda, 2012). Later, in the early 2000s, feminist organizations supported the emergence of the LGBT movement in Poland. However, in the time of democratic transition there was almost no discussion about participation of women in politics, or specifically on the question "why women's deep involvement in opposition movements does not translate into positions of power once the opposition gains power." (Fuszara, 2012).

In Agnieszka Graff's 2001 book The World Without Women, the author depicts the lack of political representation of women and marginalization of women's issues. Graff, as the leading Polish feminist educated in the West on 'second wave' literature, noticed that problems of women's rights protection and gender equality have their origin in a low representation of women in decision-making bodies. She was certainly not alone in diagnosing the state of political underrepresentation, but is just one out of several prominent women who stood behind the organization of the first Congress of Women and publicly demanded the introduction of gender parity - the 50\% rule - on electoral lists.

Interestingly, the first Congress of Women brought together women representing different social or political groups, and most importantly women of different religious (non-religious) backgrounds and social or professional origins. All of these women shared the conviction that the past twenty years of democratic transformation had not improved their situation. ${ }^{2}$ On the contrary, they found themselves adversely affected by neoliberal changes and deprived of many social benefits and institutional support that they had previously enjoyed. The participants of the first Congress identified a long list of social problems such as the feminization of poverty, women's underrepresentation in politics and business, high unemployment, lack of effective remedies against domestic violence, the non-execution of alimony dues and a lack of respect for reproductive rights. The subsequent Congresses have complemented this list with new postulations such as corporate quotas.

Yet, while the Congress of Women is a force moving for change, there are also other domestic factors that slow down or even prevent this process. From the early years of democratic transformation, the women's cause was a subject of the ideological struggle of two opposing forces - the conservative one, aligned with the Catholic Church and based on official or less official relationships between the government (the government party members) and the Episcopate (Byrnes, 2002; Huseby, 2009); and the liberal one, intertwined with transnational human rights and the European women's movement. Unlike in other post-Communist countries, the aversion to feminism and the reinvention of traditional gender roles not only characterized the early years of democratic transition in Poland (Rubio-Marin, 2014), but also became a permanent feature of Polish society.

Currently, the most significant barrier to the advancement of women's rights, including their participation in the politics, is so-called 'gender ideology' [ideologia gender] (Sierakowski, 2014a; Sierakowski, 2014b; Díendery złe i dobre, 2014). This phrase was coined by intellectuals affiliated with the Catholic Church to denote threats to the traditional family model resulting from transformation of gender roles, same-sex partnerships or marriages, recognition of rights of gendervariant (transsexual) persons, as well as new technologies in the area of reproductive health. The word

\footnotetext{
${ }^{2}$ For the first time, the Congress of Women gathered around three thousand delegates in June 2009 in reaction to the organization of official celebrations of the twenty-fifth anniversary of Solidarity and the twentieth anniversary of the democratic transition, both of which ignored the role that women had played in those processes.
} 
'gender' was previously present in the public discourse and academia, but in 2013 it was assigned a strongly pejorative meaning. When referring to 'gender', the Catholic Church and right-wing intellectuals identify all social evil and anything that is - in their view - contrary to traditional family values or the Catholic social teaching. At present, the word 'gender' seems to replace the old phrase used by the Communists to disparage 'products of the Western civilization'. Yet, the opponents of 'gender ideology', including the Episcopate, align feminism with 'neo-Marxism'.

Clearly, the scare of 'gender ideology' has an impact on the strategies of political parties, in particular in the year of the Presidential and parliamentary elections. Today, in a country where a significant number of voters are regular Church-goers ${ }^{3}$ and recipients of popular Catholic media (Radio 'Maryja' and TV Program 'Telewizja Trwam'), ${ }^{4}$ any association of a subject matter with 'gender ideology' has the potential to freeze any rational debate and prevent political decisions that could cause a resentful reaction of the Catholic leaders. In result, even a benign regulation that serves an important social interest could be rejected, at practically any stage of the policy- or law-making process, due to the alleged connotation with 'gender ideology' and the lack of sufficiently strong political will to overcome absurdity of such argumentation. ${ }^{5}$ In this way, the scare of 'genderism' stalemated the ratification of the Istanbul Convention on preventing and combating violence against women and domestic violence. ${ }^{6}$

Thus, any further progress of gender parity or quota projects is likely to fail unless political circumstances change. Evidently, the diagnosis made by Agnieszka Graff in 2001 remains valid today - Polish politics is done in the cabinets, to which women are not frequently invited (Graff, 2011b). Moreover, female candidates and women's issues are not treated seriously. While the conservative parties promote the traditional role of women as mothers and homemakers, the left-wing parties treat women's issues instrumentally. Paradoxically, the ruling coalition (Civic Platform and the Polish People's Party) does not radically differ in their approach to ideological issues from the main opposition party (Law and Justice). In many regards, patriarchal views also dominate public opinion. At the same time, one should notice that the society divided among those who support and oppose conservative ideology, and petrification of traditional gender roles, is far more diverse in its represented attitudes. For example, it includes women who share conservative beliefs on the traditional family and feminist postulations concerning the public sphere (Kułakowska \& Łuksza, 2015). ${ }^{7}$

\footnotetext{
${ }^{3}$ According to the data of the Polish Statistical Institute of the Catholic Church over $40 \%$ of adult population are regular church-goers See: http://iskk.pl/kosciolnaswiecie/75-dominicantes.html

${ }^{4}$ Radio 'Maryja' is regularly listened by approximately $10 \%$ of adult population. See: http://www.cbos.pl/SPISKOM.POL/2011/K_168_11.PDF
}

${ }^{5}$ For example, the draft law on legal gender reassignment is opposed for the reason of creating a possibility for persons who would reassign their gender only for the purpose of entering into a marriage that is restricted for persons of different gender. Such argumentation is blatantly absurd and leads to confusion, mistrust and a "chilling effect" with respect to the recognition of rights of sexual minorities.

${ }^{6}$ On 18 December 2012, Poland signed the Istanbul Convention on preventing and combating violence against women and domestic violence after "a heated debate about some aspects of this Convention, particularly on the chapter concerning prevention of violence against women and connections between gender stereotypes and violence, as well as links between gender equality and violence." (Kozłowska-Rajewicz, 2013). The Convention was ratified by the President, Bronisław Komorowski, on 13 April 2015, in the course of his run for reelection, in a symbolic place - the Center for Women's Rights. Notwithstanding this gesture, the President lost the campaign, while the succesful candidate, Andrzej Duda, openly criticized the Convention and was against its ratification.

${ }^{7}$ The authors analyze the autobiography of the First Lady as the attempt to reinterpret the Polish twentieth-century history 'by dismantling its male-oriented perspective with restored feminine "little narratives." They maintain that Danuta Wałęsa is an example of a unique post-socialist feminine sensibility, combining conservative ideology with the feminist voice about her public role. 


\section{Gender equality and the process of europeanization}

The Europeanization process, including the accession to the Council of Europe and the European Union, was a major step to implement the minimum standard of protection against gender discrimination in Poland. However, it is hard to abstract the impact of the EU on the realization of gender equality in Poland from the impact of other international authorities like the UN Human Rights Committee or the CEDAW Committee, the Council of Europe or the European Court of Human Rights, or international and European women's movements (Grabowska, 2014). Yet, gender equality was clearly understood as an element of the European Union conditionality. The transposition of the European Union anti-discrimination law in the Polish legal system not only harmonized the standard of protection, but also raised public awareness about gender equality in the field of employment and social protection. ${ }^{8}$ However, EU law could hardly be seen as a source of re-legitimization of gender equality in Poland. Rather, gender equality is still perceived as a part of EU treaty obligations in a narrow context of employment and social protection, and not internalized as a 'living' principle of a liberal democratic state.

Certainly, Polish membership in the EU did not only necessitate changes in the law, but also in government policies ${ }^{9}$ and activities implementing the principle of gender mainstreaming (Rutkowska, 2008) by all types of recipients or beneficiaries of EU funds. ${ }^{10}$ In the law, aside from the early amendments of labour law introduced in the course of the accession process, the adoption of the horizontal anti-discrimination legislation was motivated by the fear of sanctions for nonimplementation of EU directives. Sadly, the poor quality of this legislation deems its application practically impossible. ${ }^{11}$ On the one hand, in comparison with other vulnerable groups in Poland, women are relatively better protected in the area of employment. ${ }^{12}$ On the other hand, the availability of EU funds created a 'demand' for projects aimed at professional activation of women, without taking into consideration the structure of the labour market or making an attempt to change the common pattern of denying women the status of a full-time employee. Consequently, women were deprived of all employment-related protection of their social rights (Charkiewicz, 2012).

In this sense, the EU membership and the availability of EU funds had an impact on the institutional strategies of human rights, particularly for women's organizations, and it also strengthened the watchdog role of organizations in monitoring government policies and activities. In their watchdog role, organizations often use the EU as a bogeyman against the government's lack of commitment to gender equality. Furthermore, as a result of the Europeanization process, women's organizations

\footnotetext{
8 “Równouprawnienie ptci?,” Opinion poll (BS/31/13), CBOS, Warsaw 2013.

${ }^{9}$ See the first National Program for Equal Treatment for years 2013-2016 [Krajowy Program na rzecz Równego Traktowania na lata 2013-2016] adopted by the government on 10 December 2013.

${ }^{10}$ In the wake of the 'war on gender' in Poland and the opposition of the Catholic Church against gender mainstreaming programs in the field of education, feminist organizations requested information from the Ministry of Regional Development about the realization of gender mainstreaming by Catholic organizations in the programs funded by the EU structural funds.

${ }^{11}$ Act of 3 December 2010 on the implementation of some of the provisions of the European Union with regard to equal treatment, Journal of Laws 2010 No. 257, Item 1700. This law introduces a minimum standard of protection against discrimination required by the EU. It is criticized for a limited personal and material scope of protection and ineffective sanctions. Moreover, it did not introduce an independent equality body in charge of protection against acts of discrimination committed either by public or private actors, since the authority and responsibility in this area is shared by an independent organ - the Ombudsman, whose competence falls short of counteracting discrimination stemming from private bodies, and a government representative - the Plenipotentiary for Equal Treatment.

12 7th and 8th Periodic Report of the Government of the Republic of Poland for the period of 2002-2010 and the Alternative Report on the implementation of the Convention on the Elimination of All Forms of Discrimination Against Women (CEDAW) submitted to the UN Committee on the Elimination of Discrimination Against Women (CEDAW Committee).
} 
entered new institutional relations with European and international institutions and organizations (Choluj \& Neususs, 2004), as well as governmental or non-governmental domestic organizations and addressees of their programs (Grabowska, 2014; Fuszara et al., 2008). However, the new institutional relations of Polish women's organizations at the European level did not lay down a foundation for a national umbrella representation of Polish women at the European Women Lobby, nor change the polarization of the women's movement in Poland (Regulska \& Grabowska. 2007).

Yet, female NGO activists serve as experts in various government programs. The process of inclusion of women experts as well as feminist postulations in policy-making is a noticeable trend, which broadens the scope of the public debate on gender equality and inserts the women's perspective. Yet, as rightly noticed by Małgorzata Fuszara (2008), who herself was appointed as the Government Plenipotentiary for Equal Treatment in 2014, the new scope of the public debate makes new radicalisms arise. However, the inclusion of women experts in the government often is only a form of an artificial partnership because their voice is not taken seriously, they occupy less important functions (with some noble exceptions such as the Prime Minister Ewa Kopacz), ${ }^{13}$ or they remain controlled by male 'patrons'.

Although women are in some ways represented in decision-making positions, policy outcomes remain beyond the reach of women's organizations save the exceptional circumstances when they coincide with the political leadership's goals (Jovenduski \& Guardagnini, 2010: 164). In the area of public policy, the shift towards gender mainstreaming accentuated gender equality rather than the unequal position of women. Whereas this shift from 'women' to 'gender' and 'rights' to 'opportunities' enabled the inclusion of gender equality in the mainstream of policy-making, it also disabled any serious debate about other areas of inequality between men and women such as reproductive rights, gender-based violence and violence against women (Grabowska, 2014).

Due to the fragmented nature of EU anti-discrimination law (Schiek, 2009), the actual impact of the EU on gender equality in Poland is, in practice, limited to the area of employment and social protection. Meanwhile, the prohibition of discrimination between men and women in access to publicly offered goods and services seems to be less relevant. Likewise, the implementation of gender mainstreaming in government policies is limited to mobility and equal opportunities for men and women in the labour market and public administration. Furthermore, government activities concerning gender equality are mostly financed by EU funds; thus, they remain related to EU macroeconomic priorities (Grabowska, 2014). In this context, one could even argue that the piecemeal nature of EU anti-discrimination directives in fact reinforces the stereotype that women need protection in economic and social spheres of life, rather than helping to shift the paradigm from the equality to the full enfranchisement model (Rodriguez Ruiz \& Rubio-Marin, 2008).

On the one hand, the intervention through EU legislation in existing economic and social relations brought an important change to the social perception of gender discrimination. In the early years after the transition from Communism, society did not recognize that such problems existed. Nowadays, gender discrimination in employment relations is identified and litigated in courts. ${ }^{14}$ On the other hand, the equality model is socially acceptable only to a limited extent, excluding such 'dangerous' zones as birth control or same-sex marriages. In this context, one can conclude that no political or social forces in Poland openly disagree with equality legislation in the field of employment because it does not threaten the power relationships or the culturally entrenched 'sexual contract'. Thus, it is not likely that there will be a paradigm shift in gender relationships as long as the situation remains where

\footnotetext{
${ }^{13}$ Interestingly, the position of Ewa Kopacz could also be viewed as 'instrumental' to further party goals and her rule seems to be planned as an interregnum period between the handover of the Cabinet by Donald Tusk to the appointment of a new - male - party leader after the parliamentary elections in 2015.

${ }^{14}$ According to Ministerial statistics, there are several hundred lawsuits for gender discrimination in employment filed to district courts every year.
} 
men dominate politics and corporate world, the equality-driven model of fatherhood is not socially activated, and the Episcopate blocks any legislation involving issues of public morality.

\section{Electoral gender quotas}

The electoral gender quota law was introduced as an amendment to the Electoral Code in $2011 .{ }^{15}$ It requires all types of elections based on proportional voting electoral lists to have at least $35 \%$ of either gender among their candidates. An electoral list that falls short of this requirement may not be registered. The adoption of electoral gender quota law has rightly been claimed a success of the 2009 Congress of Women, which supported a citizens' initiative leading to the presentment of a draft on gender parity that was later exchanged for a $35 \%$ gender quota. In contrast to other countries with legislative gender quotas, the Polish law was a product result of a bottom-up process and it has a strong democratic legitimacy (Śledzińska-Simon \& Bodnar, 2013). Notably, the electoral quota system has not been challenged before the Constitutional Tribunal, although some recent amendments to the Electoral Code have already been struck down as unconstitutional. ${ }^{16}$

Adoption of the electoral gender quota law was not a part of the government's agenda, but rather the outcome of successful mobilization of the women's movement in using the unparalleled circumstances of an early presidential campaign following the death of the President of Poland in a plane crash in Smolensk. In this triangle relationship between the government, the legislature and the social movement, the gender parity bill was put forward by a social movement that won government support in the form of the $35 \%$ gender quota bill in the legislative process. While right-wing political parties ideologically contested both the electoral gender parity and the quota, the left-wing parties supported the bill in order to increase their popularity and attract women voters. Although the Congress of Women's initiative was supported by many EU-related figures like the EU Parliament head Jerzy Buzek, European women's networks, as well as EU funding, it was considered a national project that remained unrelated to the implementation of EU treaty obligations. In the debate on gender quotas, only one expert opinion emphasized that parity or quotas are consistent with the Convention on Elimination of All Forms of Discrimination Against Women (Wieruszewski \& Sękowska-Kozłowska, 2010).

In the period between the first Congress of Women in 2009 and the adoption of amendments to the electoral law in 2011, the public debate over gender parity and quota focused on the question of whether a law aimed at the advancement of women's political representation is constitutional. Notably, the issue of gender parity was already discussed in 2003 during the parliamentary debate over the draft law on equal status of men and women, when an argument for parity democracy was raised for the first time (Bisztyga, 2004: 27). However, at that time the concept of political representation based on gender did not gain enough political and social support (Żukowski, 2007). In 2011, legitimacy of gender parity and later gender quota grew in the eyes of political leaders not because of the paradigm shift, but yet again because female support was needed for a victory in the Presidential elections.

Characteristically, a statistical Pole was much more supportive of special measures favouring women's participation in the public life than a statistical politician. In 2009, according to some data, $70 \%$ of women and $52 \%$ of men were in favour of gender parity (Fuszara, 2011). Yet, the opinion polls showed more moderate social support for legislative mechanisms of promoting women's opportunities in politics (56\% respondents were in favour of and $29 \%$ against the gender parity law). ${ }^{17}$

\footnotetext{
${ }^{15}$ Act of 5 January 2011, Electoral Code, Journal of Laws 2011 No. 21, Item 112.

${ }^{16}$ Judgment of the Constitutional Court of 14 July 2011, Case no. K 9/11.

17 “Parytety prawna gwarancją większego udziału kobiet w polityce”, Opinion poll (BS/130/2010), CBOS, Warsaw 2010.
} 
In consecutive years, the level of support has slightly decreased. It is probable that the solidarity with and among women in the historical momentum of the first Women's Congress has melted.

According to the opinion poll conducted in January and February 2013, a significant part of society was in favour of increasing the number of women in the decision-making positions in the government (47\%), foundations and social organizations (47\%), political parties (46\%), public administration (42\%), and companies and enterprises (45\%). The respondents underscored that the reason behind lower participation of women in the public life is related to women's greater engagement in household duties (59\%) and male dominance in the public space (43\%). Every third respondent considered it fair that the law defines a percentage of places reserved for women on the electoral lists, whereas the majority of respondents (59\%) are against such a rule. However, respondents who are in favour of electoral gender quota opt for $40 \%{ }^{18}$

Constitutional law experts commissioned by the Bureau of Legislative Analysis in the course of the legislative process were also generally very critical both about gender parity and the gender quota. They argued that the law violates the principle of equality, as well as the principle of free and equal elections, political pluralism and internal autonomy of political parties (Skotnicki, 2010; Szmyt, 2010). Some contended that quotas on electoral lists are a form of gender discrimination, which constrains the act of voting because it demands taking gender into account in addition to political and personal preferences (Banaszak, 2009: 197-98). Reasons why all but one expert opinions were generally against the quota law probably boil down to the selection of experts - all male, senior in their academic career and with a legal education. In this context, one should consider that the paternalistic approach to gender roles was engrained even in the jurisprudence of the Constitutional Tribunal.

As noticed by Ewa Lętowska, the former judge of the Constitutional Tribunal and the first Ombudsman (in fact, the Ombudswoman), many mechanisms of the Polish legal system, including the pension system. These mechanisms petrify the status of women as carers and aim to compensate their double shift by benefits that often put women in jeopardy, such as the right to acquire a pension at a different age than men. For Łętowska, women are forced to carry out responsibilities of the state that fails to provide care to the needy, and additionally bear negative financial consequences of their 'privileged' position. Paradoxically, the state pension scheme was originally supported by women's organizations who defended women's right to pension at a different age than men. The Constitutional Tribunal upheld this rule as consistent with the principle of equality. ${ }^{19}$ Notably, in this case, the full panel comprised of 8 men and 4 women, while all 3 dissenters were women. ${ }^{20}$

Viewed against this background, the adoption of the Polish law on electoral gender quota was a breakthrough. It showed that constitutionally permissible positive measures can justify not only means that maintain the existing patterns of economic inequality between and women (such as the state pension system), but also means that aim to change male dominance. Nevertheless, the quota law is just an example of progressive legislation that has not yet resulted in social transformation, nor even the abolition of negative gender stereotypes about women in politics.

\footnotetext{
18 “Kobiety w życiu publicznym”, Opinion poll (BS/34/2013), CBOS, Warsaw 2013.

${ }^{19}$ Judgement of 15 July 2010, Case no. K 63/09 (women's pensionable age)

${ }^{20}$ The new reform of the pension system introduced a gradual equalization of the pensionable age for men and women, and the Constitutional Tribunal found it consistent with the Constitution. Judgment of 7 May 2013, Case K 43/12. However, the Tribunal also issued a signalizing decision pointing out that the pension reform should have been accompanied by effective and comprehensive employment and family policy that supports activation of certain socially vulnerable categories, as well as family responsibilities of the working persons towards children and the elderly. Decision of 17 July 2014, Case no. S 3/14.
} 
Importantly, this law could be passed without a constitutional amendment because the Constitution contains guarantees of equal rights of men and women in all spheres of life ${ }^{21}$ in addition to the general principle of equality and equal treatment (non-discrimination). ${ }^{22}$ Thus, unlike in France or Italy, no constitutional amendment was needed to recognize substantive equality between men and women in political life. Furthermore, unlike the gender electoral quota law in Spain, the Polish law has not yet been subject to constitutional review. ${ }^{23}$ However, a decision on constitutionality of this law would be useful to stop further speculation on whether positive measures applied to the electoral process are consistent with the Polish Constitution.

Until now, the $35 \%$ gender quota rule applied to the elections of the Lower House of the Parliament in 2011, the European Parliament and local government in 2014. Undeniably, in all these elections the number of female candidates grew significantly, reaching around 44\%. Whereas in 2007 there were 1428 female candidates (23\% of all candidates) running in the parliamentary elections (for the Lower House of Parliament) and 94 women (21\% of all deputies) were successful, in 2011 there were 3064 female candidates and only 110 women won a seat (24\%). Thus, in the 2011 elections the number of female candidates grew by $100 \%$, but the number of female deputies only by $3 \%$ (Flis, 2014). Similarly, in 2009 among 50 deputies to the European Parliament 11 were women, and in 2014 among 51 deputies 12 are women. Such is the case even though women occupied between $40 \%$ and $50 \%$ of the electoral lists, showing the occupation of positions by women increased by one half from 2009 ("Data concerning election statistics", 2011). Nevertheless, over time, the political representation of Polish women in the European Parliament is steadily growing. ${ }^{24}$

Yet, the electoral gender quota law has not significantly changed the composition of the legislative bodies, but rather diminished the chances of female candidates to be elected because the relation between the percent of female candidates and the percent of female deputies shrunk (Skotnicki, 2010). In turn, the number of unsuccessful male candidates decreased in 2014 in comparison to 2009, and this general number decrease is attributed to the increase of the female candidates on the electoral lists (Kublik, 2014). The lack of a significant growth of the political representation of women in the legislative bodies is usually explained in relation to the composition of the list, rather than the actual number of women on the lists. For example, the list of the left-wing coalition (Europa Plus-Twój Ruch) that reserved 50\% of its positions for women in the recent elections of the European Parliament was a strong political declaration of support for women politicians, which nevertheless did not translate into a real opportunity for the election of a single woman. One reason for this situation is the lack of a placement mandate, which is a typical way to make gender quota ineffective. Perhaps low chances for electoral success of female candidates resulted also from the lack of sufficient support through soft mechanisms boosting women's political opportunities.

In fact, the impact of the electoral gender quota law on the outcome of elections is frequently contested. In the view of Małgorzata Fuszara, the representation of women in Parliament has grown because of activities of women's organizations (e.g. trainings organized in local communities by local branches of the Congress of Women) and, in particular, because of electoral gender quotas. On the

\footnotetext{
${ }^{21}$ Article 33 (1) Men and women shall have equal rights in family, political, social and economic life in the Republic of Poland. (2). Men and women shall have equal rights, in particular, regarding education, employment and promotion, and shall have the right to equal compensation for work of similar value, to social security, to hold offices, and to receive public honours and decorations

${ }^{22}$ Article 32 (1). All persons shall be equal before the law. All persons shall have the right to equal treatment by public authorities. (2). No one shall be discriminated against in political, social or economic life for any reason whatsoever.

${ }^{23}$ Judgment of the Spanish Constitutional Court of 28 January 2008, Case no. 12/2008 upholding the law on the effective equality between men and women.

${ }^{24}$ Importantly, in European Parliament elections, the entire territory of Poland counts as one multi-mandate electoral district, and for this reason the chances to be elected are different than in the national elections. Consequently, even the top (first) position on the list of candidates does not guarantee an electoral success if a political party does not have the chance to win a mandate in a given constituency, in which it registered a separate electoral list.
} 
other hand, the leading expert in election systems, Jarosław Flis, claims that the electoral gender quota works only on the level of selection of the candidates and not at the level of election of the deputies. More specifically, Flis argues that the electoral gender quota law only increased the electoral success of male candidates because less men ran in the elections, but the same percent of men won them. These results suggest that male politicians 'agreed' upon the introduction of electoral quotas because they anticipated that the $35 \%$ rule would not endanger their leadership. Thus, women in the electoral process are often used to drive the game towards men who are the 'shooters', or women less frequently play 'shooters' while men who play 'beaters' may became 'shooters' in the end (Flis, 2014).

Flis notices that political preferences are territorially and ideologically intertwined and gender is only one, and often the least significant, factor for voters supporting big political parties. Therefore, the electoral gender quota does not make a difference in an open-list electoral system, particularly if it is combined with the practice of composing lists with a double number of candidates than the actual number of mandates to be shared. In this context, the Polish case demonstrates that the success of electoral gender quotas is context-specific. Notwithstanding the strength of the women's movement or the 'color' of the government (coalition) in power, it is conditional on such criteria as the size of electoral districts and the number of political parties taking part in the elections. In the opinion of Jarosław Flis, female candidates should receive preferential treatment from their political parties before they run in elections in order to increase their popularity, since the position on the electoral list does not create a recognizable name. Instead, an electoral list 'consummates' recognizable names, which means that political parties should 'grant' a place to a candidate according to his or her merits and popularity and should not reverse this order for the reason of gender balance. It thus follows that in the Polish context, the zipper system or gender parity could make sense if it is limited to electable ('shooter') positions corresponding to the number of mandates that a given political party (electoral committee) won in the previous election (Flis, 2014).

In sum, the process of composing electoral lists by political parties remains non-transparent, and many women activists blame political party leadership for placing women candidates on non-electable positions on the list or limiting the opportunities for women candidates to be elected. ${ }^{25}$ However, it could also be the case that gender electoral quotas are just the beginning of an incremental change in the political realm that necessitates increasing the visibility of women candidates in political parties and creating new rules governing party financing of electoral campaigns.

\section{Introducing a zipper quota system}

In 2013, two independent proposals introducing a zipper system ${ }^{26}$ and the zipper system combined with the gender parity rule were a reaction to the lack of a significant change in the political representation of women in the Parliament pursuant to the 35\% gender electoral quota law. Both the Congress of Women and the political party (left-wing oriented - Twój Ruch - 'Your Movement') that sponsored the gender parity bill argued that gender electoral parity would help to increase the substantive representation of women in politics and overcome the resistance of those (male political incumbents) who would be affected by such changes (Kublik, 2014). Remarkably, the zipper quota system was sponsored by the deputies of the government party as the realization of a promise given by the leader of this party, the former Prime Minister, Donald Tusk, during the annual conference of the

\footnotetext{
${ }^{25}$ The Civic Platform introduced internal rules mandating at least one woman in the first three places, and at least two women in the first five places on the list.

${ }^{26}$ The bill (no. 1151) was introduced by the Parliamentary Group of Women on 24 January 2013 and requires that the first two places on the electoral list registered for the elections of the Lower Chamber of the Parliament (Sejm), the European Parliament and the law-making organs of the local self-government at the provincial and regional level are based on the principle of gender parity. The rule shall apply to the consecutive two places until the $35 \%$ gender quota requirement is satisfied.
} 
Congress of Women in 2012. This gesture signals not only a symbolic relation between the women's movement and the government, but also a formal recognition of the key postulations of this movement.

The two bills were later merged in a joint proposal that maintains a 35\% gender electoral quota and requires that female and male candidates appear alternatively on the electoral lists, up to the tenth place. ${ }^{27}$ The purpose of these bills was to counteract the practice used by political parties assigning women most non-electable positions on the lists. In the course of the legislative procedure, the Bureau of Legislative Analysis commissioned five opinions of constitutional experts concerning the joint proposal, all of which considered the zipper system 'unnecessary', 'discriminatory', or generally 'unconstitutional'. Notably, all of the experts were men, while in the current Parliament, only the right-wing opposition party (Law and Justice) openly opposes the idea of gender-driven positioning of electoral candidates on the lists.

To some extent, the opinions of legal experts repeat the arguments used to criticize the $35 \%$ gender electoral quota law. ${ }^{28}$ They argue that the zipper system amounts to an unconstitutional derogation from the principle of equal treatment and violates passive electoral rights, as well as the principle of political pluralism and the internal autonomy of political parties. For some authors, the abstract principle of equality requires not equality in sharing the places, but availability of every place on the electoral list for a person of either gender (Muszyński, 2014). The opinions amicably contend that the zipper parity or quota system is too rigid because it significantly restricts the freedom of the electoral process, specifically the position of a candidate on the electoral list, while the currently binding law leaves the decision about the position of a particular candidate on the electoral list to the electoral committees (of political parties, coalitions of political parties or voters). In the same vein, the commissioned opinions perceive special measures in terms of opportunities and not mandatory rules.

Moreover, according to legal experts, positioning of women on non-electable places within a particular electoral list is not mandated by law, but a consequence of social inequality of women. For some experts, in the framework of the proportional electoral system based on open lists, it is not the place on the list, but rather the electoral campaign that seem to be decisive for the electoral success of a particular candidate (Kubas, 2008; Rakowski, 2012). Consequently, any project aimed at the advancement of the political representation of women should more specifically explain the relationship between the low number of women in politics and the voters' preferences. ${ }^{29}$ In fact, allowing a free, unrestrained vote may lead to $100 \%$ presence of either gender in the Parliament. Yet, the same argument could be used to support the zipper system as the only available means to change the negative attitude of the electorate of conservative parties towards female candidates (Matland, 2003).

According to others, electoral lists should be 'color blind' and should not take into consideration irrelevant characteristics like gender. Surprisingly, this argument was not overcome by the successful adoption of the electoral gender quota law. It is thus persistently argued that the zipper system will necessitate a selection of female candidates that is not based on merits. Moreover, it is argued that the proposed legislation is not justified by any pressing social need; thus, it is unsuitable (it will not lead to a significant increase in the number of women in the Parliament), unnecessary, excessive and

\footnotetext{
${ }^{27}$ The zipper quota bill was nevertheless withdrawn from the voting order by the sponsor because it turned out that the alternation of men and female candidates up to the tenth place on the list would in fact result in gender parity in situations when there are less than ten places on the electoral list. Jabłoński (2014) also pointed out another constitutional problem with the zipper system related to the striking down of a particular candidate from a list due to his or her death. In such a case, it would be required that a new candidate is of the same gender as the deceased one.

${ }^{28}$ Yet, some of them approve of the quota system but disapprove of the zipper quota system (Chmaj, 2011).

${ }^{29}$ Also, in the last local elections in 2010 , before the introduction of the $35 \%$ gender quota law, the place on the list did not determine the outcome of the election. This observation was true for all political parties that registered their lists (Niżyńska, 2011).
} 
disproportionate. Moreover, experts maintain that the zipper system does not advance any constitutional goal. In particular, they argue that the system does not implement any legislative obligations or human rights, but rather amounts to their violation. Another frequent argument is that social or cultural patterns of gender inequality should not be fought against with legal measures. Therefore, an adequate response to gender inequality is self-regulation of political parties, greater individualization of the electoral systems and financial incentives for political parties to include more women on the electoral lists, and providing an informational campaign about the elections (Muszyński, 2014). Furthermore, experts argue that the result of the application of the quota system was ineffective, or even contrary to its goals (Chmaj, 2011: 205).

Clearly, the constitutional experts' discourse is dominated by the equality rhetoric and the question whether the zipper parity or quota system is a constitutional means to advance de facto equality between men and women in the politics. Characteristically, most of them disapprove of positive measures (calling it 'positive discrimination') as applied to political participation, even if they approve of preferential treatment of women in social and economic life and particularly when it is justified by biological differences. Notwithstanding the CEDAW Convention, the argument is that political rights stand higher in the constitutional hierarchy than any other individual rights or freedoms and therefore they should prevail. Further, one expert argues that the Constitution does not mandate equal political representation with regard to gender; therefore, the parity or quota system lacks constitutional legitimation. Furthermore, it is argued that gender-based legislation may raise expectations of other groups (distinguished on the basis of national, ethnic or social origin, age, religion, sexual orientation, residence, economic status, profession etc.) who aim to attain an adequate (proportional) representation in the decision-making processes (Jabłoński, 2014).

In this regard, there is a consensus between legal experts who delivered their opinions to Parliament that the composition of Parliament shall not have a descriptive character, nor reflect the social structure. In this regard, taking into account the citizenship models suggested by Joni Lovenduski, Mona Lena Krook and Judith Squires (2009), Poland seems to follow the republican model, which embodies a philosophical commitment to universalism rather than politics of identity. This model of citizenship to a large extent reflects the social reality of a highly homogenous nation, in which identities other than ethnic Polish are not significantly represented. ${ }^{30}$ What seems significant about this model and legislative gender quotas in Poland is that the public discourse puts emphasis on political formal - equality and rejects anything other than an abstract notion of citizenship.

\section{Gender quotas in academia, judiciary and corporate boards}

The idea of equal gender representation in Poland is not only limited to democratic processes. There are some other fields of law where elements of gender quotas were introduced or are subjects of discussion. In addition to the electoral gender quota law, the Law on Higher Education includes a statutory requirement of gender quotas with respect to the membership in the Polish Accreditation Committee (Państwowa Komisja Akredytacyjna - PAC). ${ }^{31}$ The PAC is an independent authority, appointed by the Minister of Higher Education and Science, which evaluates the quality of higher

\footnotetext{
${ }^{30}$ The Polish republican tradition dates back to the Gentry Republic in the 17th and 18th century. The republican ideal drew on four basic commitments - deliberation about the common good, political equality, agreement and citizenship. Its commitment to deliberation about the common good was institutionalized in the form of general gentry assemblies. Political equality established so-called 'golden freedoms' that provided every nobleman with the same political rights and privileges, irrespectively of his economic status. Commitment to agreement laid down the principle of unanimity, which gave every nobleman the right to obstruct work of general assemblies, unless he agreed (liberum veto). Finally, citizenship was based on one - although economically divided - social group consisting of persons governed and, at the same time, governing under the head of an elected monarch. This concept of citizenship left the bourgeoisie and peasantry unrepresented. See Perczyński \& Vink (2000).

${ }^{31}$ Act of 27 July 2005 - Law on Higher Education, Journal of Laws, No. 164, item 1365.
} 
education in Poland. Under the Law on Higher Education, the number of female members of the PAC should constitute at least 30\%. ${ }^{32}$ This means that the Minister of Higher Education and Science should take into account gender when appointing a person as a member of the PAC.

Moreover, there is also a statutory requirement to respect the principle of gender parity in the appointment of members of the General Council of Science and Higher Education (Rada Gtówna Nauki i Szkolnictwa Wyższego - the Council). ${ }^{33}$ The Council is an advisory body, representing different academic institutions and established at the Ministry of Higher Education and Science. However, the principle of gender parity is not a mandatory rule but rather a general guideline that should be taken into consideration in the appointment process. Most probably, the non-mandatory character of this principle came as a result of problems that could occur in practice, since different institutions elect the members of the Council and the realization of gender parity would require coordination between them that seems difficult and almost impossible. Therefore, the Law on Higher Education includes just a general guideline that the appointing institutions should consider the principle of gender parity.

There is no doubt that the adoption of special measures in the appointment of members of collective advisory or control bodies in the area of higher education and science is the result of gender mainstreaming, promoted as the key mechanism of gender equality at the EU level. It is recommended both by the European Commission and the European Parliament. Yet, the specific reality of the academic world should be carefully analysed to recognize that the composition of different decisionmaking organs at universities gives priority to scholars holding at least a second academic degree (post-doctoral degree of a titular professor). In recent years, the number of women with a second academic degree has been steadily growing, but a balanced gender representation in academia cannot be simply achieved by a statutory regulation. Instead, there should be institutional mechanisms creating opportunities that help women to advance their academic careers. For example, young female researchers have different age limits to apply for research grants than men when they can indicate family responsibilities (Przybylska-Maszner \& Trosiak, 2011).

Another problem related to gender equality in academia is the participation of women in scientific conferences and seminars. There are numerous examples where panellists invited to take part in a conference in the area of humanities are only or mostly men. Yet, many members of academia protest against such practices, writing open letters or refusing to participate in such events. There is even a Facebook fan page I don't go to panels in which only men participate [in Polish: Nie chodze na panele, w których występuja tylko mężczyźni], currently followed by 1132 users. Certainly, several protests concerning the organization of conferences and seminars, in which only a male perspective is represented, started a public discussion about the low visibility of female professors or researchers. In consequence, some conference conveners observe gender balance in the conference programs whenever it is possible, taking into account the theme of a conference and the professional specialization of the invited speakers. This approach has gradually become a part of the academic best practice.

One should also notice that there are no special regulations concerning gender balance in the judiciary in Poland. However, it is claimed that the judiciary is highly feminised, especially in lower courts, whereas male judges dominate higher courts such as the Supreme Court or the Constitutional Court. On the other hand, the year 2014 may be considered ground-breaking because a woman became the President of the Supreme Court for the first time. Yet, this single appointment does not mean a gender equality revolution in the judiciary, since the Polish court system in Poland continues to promote

\footnotetext{
${ }^{32}$ Article 48 Section 4 of the Law on Higher Education.

${ }^{33}$ Article 46 Section 3 of the Law on Higher Education. In the term 2014-2017 the Council counts 32 members, including 8 women.
} 
exclusively men to higher positions and to judicial positions in higher instances. At the same time, there is no discussion in the judiciary regarding this problem (Bodnar \& Bojarski, 2012: 694-95).

Since the release of the draft of the directive on corporate gender quotas by the European Commission and the proposal to introduce gender quotas attracted the attention of Western media and literature, ${ }^{34}$ the debate on enhancing the gender balance in the corporate boards in Poland has not been serious. The proposal was to introduce the $30 \%$ gender quota in the corporate boards of state-controlled companies until 2013 and 40\% until 2014, and in 2011 the $3^{\text {rd }}$ Congress of Women put forward the $40 \%$ gender quota in listed companies. Following the example of the European Commission, the Ministry of Economy started a general debate on corporate quotas in 2013. Yet, the vice-Minister of Economy affirmed that the introduction of gender quotas in business will not take place if there is no support from the business side, although there are many arguments speaking in favour of such measures and their impact on innovativeness or effectiveness of business activities.

The typical counterargument in this type of debate is that women who are not equally qualified will be promoted to such positions, and again it is not emphasized that companies should adopt strategies of training their female managers for board positions. Other opponents of corporate quotas argued that the corporate world functions on the basis of different principles than ruling in the society. Typically, the opponents of corporate quotas claim that any intervention in corporate governance violates freedom of economic activity and property interests of shareholders. Following these principles, any appointment of members of corporate boards is expected to be not gender-based, but merit-based. Moreover, there is a strong scepticism in particular in this area of regulation against introducing equality through hard law mechanisms that, according to some experts, may not have popular support. Notably, both Chambers of Parliament declared that the proposal of the European Commission is contrary to the principle of subsidiarity. This position was also represented by the majority of legal experts commissioned by the Parliament.

Despite the criticism by business entities, some measures relating to gender quotas in companies have been introduced. Most notably, in 2013 the Minister of the State Treasury issued "good practices" ("Dobre Praktyki", 2013) with regard to equal representation of men and women in the supervisory boards of the State Treasury owned companies. According to these 'good practices,' until 2015 the Ministry of State Treasury will aim to achieve 30\% representation of women working in publicly traded companies (where the Ministry has shares) or in other key companies. The current rate of women's participation in supervisory boards of State Treasury controlled companies is $17.2 \%$. The 'good practices' indicate that the Ministry should use their right to vote in general assemblies of companies to elect new candidates to supervisory boards by taking into account not only their qualifications, but also the need to achieve proper gender representation. The Ombudswoman is currently monitoring the implementation of said 'good practices' and is also promoting their 'export' to other companies, including those privately-owned and traded in the Warsaw Stock Exchange (Letter by Ombudswoman to the Minister of State Treasury, 2013).

Moreover, according to Rule 9 of the Good Practices of Publicly-Traded Companies at the WSE, they should provide for balanced representation of men and women in management and supervisory boards. However, this rule is subject to the mechanism 'comply or explain,' and therefore the boards of the majority of companies are predominantly male with only a small percentage of participation by women. ${ }^{35}$ Therefore, the only way to change the situation is through legislative provisions (e.g. being

\footnotetext{
${ }^{34}$ Proposal for a Directive of the European Parliament and of the Council on improving the gender balance among nonexecutive directors of companies listed on stock exchanges and related measures, 14 November 2012, COM (2012) 614 final.

35 According to study prepared by the Warsaw Stock Exchange in cooperation with the Capital Markets' Institute (Instytut Rynku Kapitałowego) in 2012, women constituted $12.2 \%$ members of the management boards and $15.7 \%$ members of supervisory boards.
} 
a result of the EU law) or stronger corporate governance rules. ${ }^{36}$ The latter solution requires broad public understanding of the issue. Solutions such as voluntary signing by corporations of the Diversity $\operatorname{Card}^{37}$ contribute to the public debate, but without strong legislative requirements there will be no significant change with regard to the representation of women in business.

\section{Conclusions}

The electoral gender quota law did not bring about any radical change in women's representation in politics. However, the mobilization of women's activists and organizations related to this project moved the women's perspective into the mainstream of the politics in Poland (Graff, 2011a). Following on William A. Gamson's perspective (1975), one could say that the government response to the women's movement is mostly procedural, since it is limited to the recognition and acceptance of movement activism as a legitimate representative of social interest in policy processes. Yet, there is also incremental substantial change, which signals that the government is ready to insert some modest claims of the women's movement in its own agenda. Clearly, for feminist activists, gender parity is a long-term goal, and their strategy is to strengthen their influence on the government and in policy choices. One may notice that the relative success of the gender quota law may have impact on other areas of public life where women are underrepresented, such as academia and business.

${ }^{36}$ Potential changes to the companies' codes as a result of introducing gender quotas and on impact of the EU law on Polish company law were discussed during the conference "Gender parities in the managerial positions", organized in the Polish Parliament on 15 April 2013, by the European University Viadrina and the Polish-German Association of Lawyers.

37 The Diversity Card is a voluntary commitment of a corporation to follow various diversity rules in its operation. This international initiative started in Poland in 2012 and is supported by numerous governmental institutions. See more at http://kartaroznorodnosci.pl/pl/en. 


\section{References}

Banaszak, B. (2009). Konstytucja Rzeczypospolitej Polskiej. Komentarz. Warsaw: C.H. Beck.

Bisztyga, A. (2004). Równy status kobiet i mężczyzn - nowe wyzwanie dla polskiego legislatora. Aspekt konstytucyjny in: H. Zięba-Załucka, M. Kijowski (eds.), Zasada równości w prawie, Konferencja naukowa, Rzeszów, 16 października 2003 r., Rzeszów 2004.

Bodnar, A. \& Bojarski, Ł. (2012). Judicial Independence in Poland. In A. Seibert-Fohr (ed.), Judicial Independence in Transition (pp. 667-738). Heidelberg: Springer Verlag.

Byrnes, T. A. (2002). The Challenge of Pluralism, The Catholic Church in Democratic Poland. in: T. G. Jelen, \& C. Wilcox (eds.), Religion and Politics in Comparative Perspective: The One, the Few, and the Many (pp. 27-44). Cambridge: Cambridge University Press.

Charkiewicz, E. (2012). Gender mainstreaming do nikąd. Analiza dokumentów i programów bezzwrotnych dotacji UE 2007 -2011, Referat na konferencji NEWW i Fundacji Róży Luksemburg „Pieniądze też maja płeć”, Gdańsk, 17 maja 2012, Biblioteka Online Think Tanku Feminstycznego.

Chmaj, M. (2011). Parytet ptci w kodeksie wyborczym. In K. Skotnicki (ed.), Kodeks wyborczy. Wstęn a ocena. Warsaw: Wydawnictwo Sejmowe.

Choluj, B., \& Neususs, C. EU Enlargement in 2004: East-West Priorities and Perspectives from Women Inside and Outside the EU (Discussion Paper 7, 2004). www.frauenakademie.de/dokument/img/gender_equality_enlargedEU.pdf .

Czerwińska, J. Piotrowska, "20 lat zmian - raport. Kobiety w Polsce w okresie transformacji 19892009”, Warsaw 2009.

Data concerning election statistics. (2011). Państwowa Komisja Wyborcza. Retrieved from http://wy bory2011.pkw.gov.pl/kom/pl/statystyka.html

Dobre Praktyki [Good practices]. (2013, March 8). http://www.msp.gov.pl/pl/media/aktualnosci/251 31,Dobre-praktyki-w-zakresie-zapewnienia-zrownowazonego-udzialu-kobiet-i-mezczyznw.html.

Durda, R. (2012). Comments paper - Poland, Awareness raising activities to fight violence against women, United Kingdom, 7-8 February 2012. http://ec.europa.eu/justice/genderequality/files/exchange_of_good_practice_uk/pl_comments_paper_uk_2012_en.pdf.

Dżendery złe i dobre. Protokót rozbieżności dwóch antropologii. (2014). Więź Quarterly, Spring 2014: special issue on Genders bad and good. Protocol of disagreements of two anthropologies.

Flis, J. (2014, January 13). Opinia prawna w przedmiocie: oceny zgodności poselskiego projektu ustawy o zmianie ustawy - Kodeks wyborczy z dnia 5 stycznia 2011 r. (druk nr 1146) oraz poselskiego projektu ustawy o zmianie ustawy - Kodeks wyborczy (druk nr 1151) z Konstytucją Rzeczypospolitej Polskiej.

Fuszara, M. (2006). Kobiety w polityce. Warsaw: Trio.

Fuszara, M. (2008). Polityka i karnawat, czyli nowy ruch kobiecy w Polsce, Societas/Communitas, 2(4)-1(5), 157-172.

Fuszara, M. (2009). Kobiety w polityce dwudziestolecia (1989-2009). in: Kobiety dla Polski, Polska dla Kobiet, 20 lat transformacji, Raport, Kongres Kobiet Polskich, 187;

Fuszara, M. (2010). Participation of women in public life and women's rights in Poland. In J. Kucharczyk, \& J. Zbieranek (eds.), Democracy in Poland 1989-2009. Challenges for the future (pp. 89-100). Warsaw: Institute of Public Affairs. 
Fuszara, M. (2011). Poland: One Step Forward, One Step Back. A Polish Dance around the Quota System. In D. Dahlerup, \& L. Freidenvall (eds.), Electoral Gender Quota Systems and Their Implementation in Europe, Report for The European Parliament, the Committee on Women's Rights and Gender Equality (pp. 72-82).

Fuszara, M. (2012). Polish Women's Fight for Suffrage. In B. Rodríguez-Ruiz, \& R. Rubio-Marín (eds.), The Struggle for Female Suffrage in Europe: Voting to Become Citizens (143-157). Leiden: Brill.

Fuszara, M., Grabowska, J., \& Mizielinska, J. (2008). Wspótpraca czy Konflikt? Państwo, Unia Europejska i Kobiety. Warsaw: Wydawnictwa Akademickie i Profesjonalne.

Gamson, W.A. (1975). The Strategy of Social Protest. Homewood: The Dorsay Press.

Grabowska, M. (2014). Unia Europejska oczami kobiet: polityka rząu, równość ptci i polskie organizacje kobiece, Raport, Heinrich Böll Stiftung, 2014. http://pl.boell.org/sites/default/files/uploads/2014/07/analiza_magda_grabowska_ue_a_gender.p df

Graff, A. (2001). Świat bez kobiet. Warsaw: Wydawnictwo WAB.

Graff, A. (2011a, April 4). Polish Feminism is No Longer Ridiculed. The Guardian. www.guardian.co.uk/commentisfree/2011/apr/09/polish-feminism-gender-equality.

Graff, A. (2011b). Świat bez kobiet. Warsaw: Wydawnictwo WAB.

Huseby, D.O. (2009). The Catholic Church and the Europeanization of Anti-Discrimination Protection - The Cases of Post-Communist Poland and Croatia. Western Balkans Security Observer, 14, 102-119.

Jabłoński, M. (2014, January 13). Opinia prawna w przedmiocie: oceny zgodności poselskiego projektu ustawy o zmianie ustawy - Kodeks wyborczy z dnia 5 stycznia 2011 r. (druk nr 1146) oraz poselskiego projektu ustawy o zmianie ustawy - Kodeks wyborczy (druk nr 1151) z Konstytucją Rzeczypospolitej Polskiej.

Jovenduski, J., \& Guardagnini, M. (2010). Political Representation. In D.E. McBride, \& A.G. Mazur (eds.), The Politics of State Feminism. Innovation in Comparative Research. Philadelphia: Temple University Press.

Kozłowska-Rajewicz, A. (2013). Benefits and challenges of implementing preventive measures contained in the Convention - a national perspective, Regional Conference on the Istanbul Convention. From signature to ratification and implementation - Exchange of experiences and practices. Helsinki, 17-18 January 2013.

Kubas, S. (2008). System wyborczy a model polskiej demokracji. Studia Wyborcze, 6, 16-17.

Kublik, A. (2014, June 5). Flis: Kwoty wyborcze dla kobiet nie maja sensu, Gazeta Wyborcza. http://wyborcza.pl/1,75478,16104249,Flis_Kwoty_wyborcze_dla_kobiet_nie_maja_sensu.html \#ixzz39Gm29PGD.

Kułakowska, K., \& Łuksza, A. (2015). The Voice of Poland. The case of Danuta Wałęsa, Feminist Media Studies, 15(1): Special Issue: Mediating Post-Socialist Femininities, 53-73.

Letter by Ombudswoman to the Minister of State Treasury. (2013, December 30). RPO-712795I/12/KWŻ. http://www.sprawy-generalne.brpo.gov.pl/pdf/2012/09/712795/1778455.pdf.

Lovenduski, J., Krook, M.L., \& Squires, J. (2009). Gender Quotas and Models of Political Citizenship. British Journal of Political Science, 39(35), 781-803.

Matland, R. (2003). Zwiększanie uczestnictwa politycznego kobiet: nominacja do ciał ustawodawczych a systemy wyborcze (tłum. P. Rogala). In R. Siemieńska (ed.), Aktorzy życia publicznego. Pteć jako czynnik różnicujący. Warsaw: Wydawnictwo Naukowe Scholar. 
Muszyński, M. (2014, January 13). Opinia prawna w przedmiocie: oceny zgodności poselskiego projektu ustawy o zmianie ustawy - Kodeks wyborczy z dnia 5 stycznia 2011 r. (druk nr 1146) oraz poselskiego projektu ustawy o zmianie ustawy - Kodeks wyborczy (druk nr 1151) z Konstytucją Rzeczypospolitej Polskiej.

Nie chodzę na panele, w których wystęuja tylko mężczyźni [I don't go to panels in which only men participate] https://www.facebook.com/NieChodzeNaPaneleWKtorychWystepujaTylkoMezczy zni.

Niżyńska, A. (2011). Kandydatki w wyborach samorzadowych w 2010. Warsaw: Instytut Spraw Publicznych.

Nowakowska, U., \& Jabłonska, M. Violence Against Women. In U. Nowakowska (ed.), Polish Women in the 90's. Warsaw: Women's Rights Center.

Penn, S. (2005). Solidarity's Secret. The Women who Defeated Communism in Poland. Michigan: University of Michigan Press.

Perczyński, P., \& Vink, M. (2000). Citizenship and Democracy - a Comparative Study of Two Cases from European History. ECPR Joint Sessions of Workshops, Copenhagen, 14-19 April 2000. http://www.essex.ac.uk/ecpr/events/jointsessions/paperarchive/copenhagen/ws6/perczynski.pdf

Przybylska-Maszner, B., \& Trosiak, C. (2011). Uwarunkowania awansu zawodowego kobiet na polskich uczelniach, Przegląd Politologiczny, 3, 167-183. http://wnpid.amu.edu.pl/ images/stories/pp/pp-3-2011/167-184.pdf.

Rakowski, M. (2012). 'Lokomotywy' czy 'odkurzacze'? - O wynikach liderów list wyborczych. Polemika z Wojciechem Peszyńskim. Studia Wyborcze, 13, 61-77.

Regulska, J., \& Grabowska, M. (2007). New Geographies of Women's Subjectivities in Poland. In M. Murphy et al. (eds.), Global babel: Interdisciplinarity, Transnationalism, and the Discourses of Globalization (pp. 102-42). Newcastle: Cambridge Scholarly Publishing.

Rodriguez Ruiz, B., \& Rubio-Marín, R. (2008). The Gender of Representation: on Democracy, Equality and Parity. International Journal of Constitutional Law, 6, 287.

Rubio-Marín, R. (2014). The Achievement of Female Suffrage in Europe: on Women's Citizenship. International Journal of Constitutional Law, 12(1), 4-34.

Rutkowska, E. (2008). Gender mainstreaming in Poland: a case study. In A. Grzybek (ed.), Gender Mainstreaming. How Can We Successfully Use Its Political Potential (pp. 87-120). Warsaw: Heinrich Boell Foundation.

Schiek, D. (2009). From European Union non-discrimination Law towards Multidimensional Equality Law in Europe. In D. Schiek, \& V. Chege (eds.), European Union Non-Discrimination Law: Comparative Perspectives on Multidimensional Equality Law (pp. 3-47). London: Routledge.

Sierakowski, S. (2014a, January 26). The Polish Church's Gender Problem. New York Times. http://www.nytimes.com/2014/01/27/opinion/sierakowski-the-polish-churchs-genderproblem.html?_r=0.

Sierakowski, S. (2014b, July 3). Poland's Culture War Rages On. New York Times. http://www.nytimes.com/2014/07/04/opinion/slawomir-sierakowski-polands-culture-war-rageson.html.

Skotnicki, K. (2010). Opinia w sprawie wprowadzenia parytetu płci na listach wyborczych. Przegląd Sejmowy, 3, 129.

Śledzińska-Simon, A., \& Bodnar, A. (2013). Gender Equality from Beneath: Electoral Gender Quotas in Poland. Canadian Journal of Law and Society, 28(2), 1-18.

Szczuka, K. (2004). Milczenie owieczek. Rzecz o aborcji. Warsaw: Wydawnictwo WAB. 
Szmyt, A. (2010). Opinia w sprawie wprowadzenia parytetu płci na listach wyborczych. Przegląd Sejmowy, 3, 137.

Wieruszewski, R., \& Sękowska-Kozłowska, K. (2010). Opinia w sprawie wprowadzenia parytetu płci na listach wyborczych. Przegląd Sejmowy, 3, 14

Żukowski, A. (2007). Wybory a reprezentacja polityczna kobiet. Studia Wyborcze, 3, 62. 
